\title{
The Present Role and New Potentials of Anaerobic Fungi in Ruminant Nutrition
}

\author{
Thomas Hartinger *(D) and Qendrim Zebeli
}

\section{check for}

updates

Citation: Hartinger, T.; Zebeli, Q. The Present Role and New Potentials of Anaerobic Fungi in Ruminant Nutrition. J. Fungi 2021, 7, 200. https://doi.org/10.3390/jof7030200

Academic Editor: Laurent Dufossé

Received: 23 February 2021

Accepted: 5 March 2021

Published: 10 March 2021

Publisher's Note: MDPI stays neutral with regard to jurisdictional claims in published maps and institutional affiliations.

Copyright: (c) 2021 by the authors. Licensee MDPI, Basel, Switzerland. This article is an open access article distributed under the terms and conditions of the Creative Commons Attribution (CC BY) license (https:// creativecommons.org/licenses/by/ $4.0 /)$.
Institute of Animal Nutrition and Functional Plant Compounds, University of Veterinary Medicine Vienna, 1210 Vienna, Austria; qendrim.zebeli@vetmeduni.ac.at

* Correspondence: thomas.hartinger@vetmeduni.ac.at

\begin{abstract}
The ruminal microbiota allows ruminants to utilize fibrous feeds and is in the limelight of ruminant nutrition research for many years. However, the overwhelming majority of investigations have focused on bacteria, whereas anaerobic fungi (AF) have been widely neglected by ruminant nutritionists. Anaerobic fungi are not only crucial fiber degraders but also important nutrient sources for the host. This review summarizes the current findings on AF and, most importantly, discusses their new application potentials in modern ruminant nutrition. Available data suggest AF can be applied as direct-fed microbials to enhance ruminal fiber degradation, which is indeed of interest for high-yielding dairy cows that often show depressed ruminal fibrolysis in response to high-grain feeding. Moreover, these microorganisms have relevance for the nutrient supply and reduction of methane emissions. However, to reach AF-related improvements in ruminal fiber breakdown and animal performance, obstacles in large-scale AF cultivation and applicable administration options need to be overcome. At feedstuff level, silage production may benefit from the application of fungal enzymes that cleave lignocellulosic structures and consequently enable higher energy exploitation from forages in the rumen. Concluding, AF hold several potentials in improving ruminant feeding and future research efforts are called for to harness these potentials.
\end{abstract}

Keywords: additive; anaerobic digestion; cattle; enzyme; anaerobic fungi; herbivore; Neocallimastigomycota; rumen; silage

\section{Introduction}

The metabolic processes in the rumen are of crucial importance in ruminant nutrition and decisively influence the host supply with energy and valuable nutrients. Hence, the rumen microbiota is of key interest in this interdisciplinary research field. Although it is common consensus that the ruminal ecosystem comprises various distinct microbial groups, i.e., bacteria, protozoa, archaea, fungi, and viruses [1], the myriad of microbiota-related studies in ruminant nutrition, however, are predominantly focusing on bacteria. Whilst also the domains archaea and protozoa gained attention in terms of methane emissions or intra-ruminal nitrogen $(\mathrm{N})$ recycling [2,3], AF (phylum Neocallimastigomycota) have yet been widely neglected in the wider ruminant nutrition research. However, these obligate anaerobes are commensals along the gastrointestinal tract of ruminants, being mainly present in the forestomach [4], and truly vital for sufficient fiber degradation by means of expressing various carbohydrate-active enzymes (CAZymes), which can be organized in cellulosomes, as well as physically penetrating plant material via rhizoidal systems [5-7].

In fact, AF and their capabilities are highly recognized among microbiologists and comprehensive scientific efforts have been made regarding their taxonomy, lifecycle, and metabolic characterization, which recently was excellently summarized by Hess et al. [5]. Notwithstanding, AF appear to be equally relevant to ruminant nutritionists, who continually seek for strategies to optimize ruminal fiber degradation, a process in which AF are indeed substantially involved [5,7]. Likewise, this microbial clade seems significant for further aspects related to modern livestock feeding. Therefore, by portraying the current 
perception of AF in ruminant nutrition and outlining their potential in this research field, this review extends the perspective on AF and aims to stimulate scientific discourse on their relevance in modern ruminant feeding as well as sensitize ruminant scientists for these hidden champions in the gut. Since Hess et al. [5] provide an extensive status quo on AF live cycle and taxonomy, the present review will not cover those aspects, albeit a new fungal taxon has again been isolated in the meantime [8]. Similarly, the reader is further encouraged to consult the article of Vinzelj et al. [9] for general basics on AF as well as thorough considerations about their cultivation.

\section{Current Perception of Anaerobic Fungi in Ruminant Nutrition}

In terms of microbiota-related research, the field of ruminant nutrition is doing tremendous efforts to understand how the gut microbiota can be shaped by feeding to optimize rumen fermentation, nutrient provision to the host, as well as gut health and ultimately prevent diseases along with improving animal performance. Thereby, major focus is placed on the rumen, i.e., the gut segment that harbors a highly complex microbial community enabling the energetic utilization of structural carbohydrates as well as providing key nutrients, such as protein and vitamins, to the host animal [1,10]. In the last decades, the hindgut microbiota also became a subject of increasing interest for ruminant nutritionists, particularly in relation to high-grain feeding and associated microbial dysbiosis [11]. With few exceptions and irrespective of gut segment investigated, bacteria represent the target domain in nutritional studies with ruminants, as exemplified by the survey of Henderson et al. [12], who investigated the influence of diet on the ruminal microbiota composition on a global scale, exploring bacteria, archaea, and protozoa. Anaerobic fungi, however, have not been included in this specific study and although AF have been introduced as potent fiber degraders in relevant ruminant nutrition journals very early [7], these microorganisms remain mostly unconsidered so far [12-16]. Therefore, including AF in future ruminant nutrition studies should be the logical outcome, as otherwise, a holistic capture of the rumen microbiota and its implications on nutrition seem hardly feasible. As a complemental note, the authors like to direct additional awareness to AF in the hindgut, which may be more vital for equines at first sight. However, a considerable number of active AF is present in the ruminant's lower gut [4,17] and since concentrate-rich feeding can shift substrate degradation from the rumen to the hindgut [18], it would be irrational to disregard the fungal population in this part of the gastrointestinal tract.

Interestingly, the rumen simulation technique of Czerkawski and Breckenridge [19] constitutes an in vitro system suitable for long-term incubation that is widespread in ruminant nutrition and may be an excellent option for studying rumen AF in all its aspects. In fact, this system has already been used in the past to explore these microorganisms [20-22] and due to its continuous flow of the liquid fraction was actually deemed a better approach for investigating rumen AF than batch cultures [20].

\subsection{Ruminal Fiber Degradation}

It is well established that AF contribute significantly to ruminal fiber degradation by attacking plant cell walls in two ways, i.e., enzymatically, and physically [5-7]. Remarkably, recent research showed the affinity of fungal CAZymes for recalcitrant fiber [23], which may explain the particular significance of AF when feeding low-quality forage to ruminants. The authors, however, will not review explicitly on the enzymatic repertoire of AF as fungal CAZymes and the associated cellulosomes have been the subject of earlier reviews $[5,24]$ and a current list of all fungal CAZymes discovered so far is provided by Hess et al. [5].

The synergistic activity of CAZymes, either individually or organized as cellulosomes, and mechanical penetration of plant cell wall by fungal hyphae results in an enhanced cleavage of fibrous structures by AF [5], which will also increase the access for other rumen cellulolytics and likely also proteolytics [2]. Indeed, cell wall degradation by AF can be higher than by bacteria under certain in vitro conditions [25,26] but quantifying the exact fungal contribution to fiber breakdown in the rumen is difficult. However, 
several in vitro and in vivo studies demonstrated the association between AF and an improved fiber degradability [25-28], which is also suggested by recent in vitro data from Ma et al. [26]. These authors investigated the impact of co-culturing methanogens with either $\mathrm{AF}$ or bacteria on in vitro degradation of rice and wheat straw, observing higher dry matter and fiber degradation in the presence of AF, the extent of which was similar to lignocellulose breakdown by whole ruminal content. Interestingly, acetate production was even higher in the co-occurrence of $\mathrm{AF}$ and methanogens than for whole ruminal content or methanogens and bacteria [26], indicating a pivotal involvement of AF in providing this milk fat precursor [29] to the host as also evidenced by others [30] and the generally high acetate formation of $\mathrm{AF}$ [31].

Apart from fiber degradation taking place in the rumen, about 5 to $10 \%$ of microbial carbohydrate degradation in dairy cows is assigned to the hindgut [11], meaning the microbiota at this intestinal site, and in this way also $\mathrm{AF}$, to be surely relevant regarding total tract fiber degradation in ruminants. As mentioned before, mainly bacteria tended to be routinely studied when investigating the rumen and hindgut microbiota under different feeding regimes [12-16]. Thus, in order to understand better the complex mechanisms of fiber utilization in the gut of ruminants, AF should be added to the list of microbial targets.

\subsection{High-Grain Feeding}

High-grain-induced gut disorders and their implications on animal health constitute one major subject of intensive ruminant production systems [32] and various studies have analyzed the effects on the microbiota in both the rumen and the hindgut [11,32-34]. Anaerobic fungi, however, have not been included in the majority of these investigations. Available data predominantly rest upon quantitative real-time PCR and indicate that total fungal abundances in general seem to diminish with increasing starch content of the diet $[35,36]$, which matches the lower ruminal fiber degradation that comes along with such feeding regimes [37]. However, when looking at the fungal composition, a more sophisticated impact on AF by diet becomes apparent. As found for bacteria [34], also the $\mathrm{AF}$ richness and diversity in the rumen declines in response to high-grain feeding of dairy cows $[36,38,39]$, which was also observed in the rumen of goats switched from low to high-grain [40]. However, not all taxa are affected negatively [36,41,42] and certain ones indeed proliferate with concentrate-rich feeding, i.e., Neocallimastix, Piromyces, and Feramyces [36,42]. In consequence, these AF could be of specific interest regarding highyielding dairy cows, which are typically fed high-grain diets during lactation and frequently suffer from impaired ruminal fiber degradation [37]. Thus, complementing AF in future studies on high-grain feeding will provide a more integrated view on alterations in the gut microbiota, which in turn could evince alternative strategies to alleviate gut dysbiosis and its consequences on ruminants. In addition, since parity has recently been recognized as a biological factor that determines the ruminant's resilience against grain-induced gut dysbiosis and associated health disorders [32,43], it is worth an additional remark that the ruminal AF community seems to be not affected by parity of dairy cows receiving low- or high-grain diets [39].

So far, the investigations on the diversity of fungal community in ruminant nutrition studies were based on sequencing the internal transcribed spacer 1 (ITS1) region, which is still commonly accepted but will likely be outcompeted by the future use of the large 28 S rRNA subunit-solely or in combination with ITS1 [5,31,44]. This new barcoding locus shows a similar resolution as ITS1 [45] but is devoid of its drawbacks, such as a high heterogeneity within ITS1 sequence clones [31]. Consequently, prospective ruminant nutrition studies can directly benefit from those refinements in phylogenetic marker candidates and hence improve the knowledge acquisition of coming research.

\subsection{Emission Reduction}

Apart from high-grain feeding, reducing the environmental footprint of dairy and meat production represents a further important subject of ruminant nutrition. Indeed, a 
sustainable agriculture is of high public interest and in that sense equally relevant to ruminant nutritionists, who insistently pursue to reduce livestock-related emissions, primarily methane, by the use of diverse dietary strategies. Thereby, options such as chemical inhibitors, nitrate, or lipids have been investigated concerning their effect on rumen methanogenesis, fermentation, and microbiota with mainly archaea and protozoa as the main targets of these methane mitigation concepts [3]. Despite this sound strategy with by all means promising outcomes of $20-40 \%$ methane reduction [46], AF may constitute a further facet for solving this challenge since methanogens and AF live in a close relationship [47] as demonstrated by substantial cross-feeding of hydrogen and other metabolites [47-49]. Likewise, the fungal CAZyme expression and cell wall-degrading activity are increased when culturing AF with methanogens [49-51], indicating a beneficial relation between these microbial groups, which is confirmed by higher archaeal methane production from straw when co-cultured with rumen AF than with rumen bacteria [26]. Moreover, methane mitigation of up to $23 \%$ by grape seed meal supplementation was earlier associated with decreased total fungal abundance rather than directly with methanogens [22]. Thus, it seems indeed worth to have a closer look at AF regarding their enmeshment in ruminal methanogenesis, particularly during dietary methane mitigation treatments.

In this context of livestock-related emissions, AF have previously attracted the attention of ruminant nutritionists regarding their participation in intra-ruminal $\mathrm{N}$ recycling and the associated environmental pollution by $\mathrm{N}$ compounds [2]. Certain fungal strains, such as Neocallimastix frontalis PNK2, possess high extracellular proteolytic activities [52] and may contribute to an inefficient $\mathrm{N}$ utilization by ruminants. In contrast, AF administration enhanced $\mathrm{N}$ retention in growing buffaloes [28] and the overall proteolytic capacity of AF seems limited $[2,26]$, meaning a definite statement in this regard seems yet not possible.

\subsection{Nutrient Source}

In addition to the better understanding of their function in the microbial gut community, AF also matter as a protein source for the ruminant. The large majority of crude protein absorbed in the duodenum originates from rumen microbes [53] and AF can represent up to $20 \%$ of this microbial biomass [17], thus being surely relevant in terms of amino acid (AA) provision to the host animal. Again, nutritionists have so far focused on microbial protein derived from either rumen bacteria or protozoa [53,54]. In fact, rumen AF possess a highly favorable AA profile and fungal AA were highly digestible for sheep, i.e., showing 90-98\% true AA digestibility $[55,56]$. In spite of such values, extensive research is still needed assessing the actual quantity of fungal protein reaching the small intestine as AF change in abundance under different feeding regimes [36] or may escape sequestration by lasting in the rumen fiber mat.

Apart from constituting a protein source, AF such as Orpinomyces sp. are also substantially involved in the ruminal biohydrogenation of linoleic acid [57,58], thus producing conjugated linoleic acids that are absorbed by the host animal. These specific fatty acids can exert diverse health benefits on the ruminant, e.g., a reduced prevalence for hyperketonemia during early lactation as well as modulatory influences on bovine immune cells [59,60], and are further discussed to have anti-carcinogenic effects in humans that consume ruminant-derived products [61]. Consequently, AF significantly improve the nutrient profile for the host, which should be considered when assessing the nutrient supply of ruminants. Whether rumen AF can also synthesize provitamins and vitamins, as has long been known for yeasts and other fungi [62], remains the subject of future research.

\subsection{Feedstuffs}

Microorganisms play a central role in animal feed science, either by being a major part of the feedstuff, e.g., in brewers' grains, or by their metabolic activity that is capitalized on conserving feedstuffs for ruminants. Silages constitute a main forage source fed to ruminants in all production systems worldwide and microbial additives are frequently applied during ensiling to improve lactic acid fermentation in the silo [63]. Due to the 
outstanding relevance of silages in ruminant nutrition and the yet untapped potential of AF in this forage conservation method, this field will be elucidated in a separate chapter below.

Likewise, probiotic feed supplements are commonly administered to improve the performance and health of ruminants, particularly since concerns have arisen about the use of antibiotic growth promoters [64]. Supplying exogenous AF to ruminants has been tested sparsely with indeed promising outcomes, and the current applicability of AF as microbial feed additives with its related obstacles will be thoroughly scrutinized in the following chapter.

\section{Anaerobic Fungi as Feed Additives for Ruminants}

Beneficial effects of the probiotic AF strain Piromyces sp. FNG5 on ruminal fermentation and performance of buffaloes fed wheat straw and concentrate have been demonstrated by Paul et al. [28]. These authors observed improved ruminal degradation of fiber fractions and organic matter, as well as a higher $\mathrm{N}$ retention and increased total tract digestibilities of organic matter and fiber fractions in AF-treated ruminants, which was likely caused by higher activities of fungal cell wall-degrading enzymes [28]. As outlined in Table 1, also others showed enhanced growth and milk performance of calves and lactating buffaloes, respectively, as well as higher ruminal fiber degradability in response to administration of different AF strains [65-68]. Hereby, it is notable that most of these applied fungal strains were isolated from non-domesticated ruminants, suggesting that wild herbivores may be valuable reservoirs for future probiotic candidates.

Despite such indeed auspicious findings about treatments with AF cultures, the administration form needs to be considered, too, as it is decisive for the practical meaning and feasibility. The AF were introduced into the rumen on a daily or occasionally on a weekly basis as fresh cultures using oral drenching [65-67], the rumen cannula [28,68], or by immediately feeding fresh fungal cultures mixed with concentrate [28]. Such laborious approaches are limited to academic purposes only but certainly not implementable in work routines of ruminant livestock production. Due to the resilience of the rumen microbiota against exogenously added microorganisms [69], a one-off drenching dose with AF, however, would not provide a lasting effect and probiotic AF must be administered to the animals continuously. The vast majority of feed additives for ruminants is supplied via the diet and this may constitute the sole easy to apply option for AF-based probiotics, as well. However, fungal cultures are highly susceptible to oxygen and in order to use them as feed additives that need to be storable, further preventing measures are indispensable. In this regard, the initial findings from Paul et al. [70] may be of particular interest, showing that the weekly feeding of Neocallimastix sp. CF-17 cells, specifically encapsulated, and hence protected from harmful influences, increased the growth performance of buffalo calves during their first four weeks of life-although, it must be noted that the deployed encapsulation enabled a protection of AF from air for only up to $12 \mathrm{~h} \mathrm{[70],} \mathrm{thus} \mathrm{pointing}$ out to the tedious development work still to be done. Apart from encapsulation methods, tenacious AF resting forms that are commonly found in feces and withstanding air exposure and desiccation for several months [4], might hold a further chance for the future that should be pursued. Notwithstanding this, growing fungal cultures on a large scale seems yet not possible $[9,71]$, and besides investigating the suitability of AF encapsulation and fungal resting forms, also advances in cultivation are the prerequisite to enable the full-scale application of probiotic AF in ruminant livestock industry. 
Table 1. Overview of studies investigating anaerobic fungi (AF) as feed additives in ruminants.

\begin{tabular}{|c|c|c|c|c|}
\hline AF Strain & Investigated Ruminant Species & AF Administration Form & Results $^{1}$ & Reference \\
\hline $\begin{array}{l}\text { Piromyces sp. FNG5 isolated } \\
\text { from wild blue bull }\end{array}$ & $\begin{array}{l}\text { Buffaloes fed wheat straw ad } \\
\text { libitum with additional } \\
\text { concentrate } \\
\text { (up to } 50 \% \text { of DM intake) }\end{array}$ & $\begin{array}{l}\text { Fresh fungal culture medium } \\
\text { mixed with concentrate before } \\
\text { morning feeding, } \\
\text { daily administered }\end{array}$ & $\begin{array}{l}\text { Increased total tract digestibility of } \mathrm{DM}^{2} \text {, organic matter, } \mathrm{NDF}^{3} \text {, } \\
\text { and } \mathrm{ADF}^{4} \\
\text { Increased nitrogen retention }\end{array}$ & {$[28]$} \\
\hline $\begin{array}{l}\text { Piromyces sp. FNG5 isolated } \\
\text { from wild blue bull }\end{array}$ & $\begin{array}{l}\text { Buffaloes fed wheat straw ad } \\
\text { libitum with additional } \\
\text { concentrate } \\
\text { (up to } 50 \% \text { of DM intake) }\end{array}$ & $\begin{array}{l}\text { Fresh fungal culture medium via } \\
\text { the rumen cannula, } \\
\text { daily, administered, }\end{array}$ & $\begin{array}{l}\text { - Increased DM intake } \\
\text { - Increased in situ disappearance of NDF and ADF } \\
\text { - Higher ruminal concentrations of total } \mathrm{SCFA}^{5} \text {, acetate, propionate, } \\
\text { butyrate, valerate, iso-butyrate, and iso-valerate } \\
\text { Higher abundance of total fungi, large holotrichs, as well as total, } \\
\text { cellulolytic, and hemicellulolytic bacteria in the rumen } \\
\text { - Higher ruminal concentrations of carboxymethyl cellulase, } \\
\text { microcrystalline cellulase, xylanase, acetyl esterase, ferulyl } \\
\text { esterase, and protease }\end{array}$ & [28] \\
\hline $\begin{array}{l}\text { Orpinomyces sp. C- } 14 \text { isolated } \\
\text { from domesticated cattle }\end{array}$ & $\begin{array}{l}\text { Crossbred calves fed wheat straw } \\
\text { and concentrate }(50: 50 \text { on a DM } \\
\text { basis) with additional green oats } \\
(1 \mathrm{~kg} / \mathrm{d})\end{array}$ & $\begin{array}{l}\text { Fresh fungal culture medium by } \\
\text { oral drenching, weekly } \\
\text { administered }\end{array}$ & $\begin{array}{l}\text { - Increased daily and total body weight gain } \\
\text { - Increased total tract digestibility of DM, crude protein, NDF, } \\
\text { and ADF } \\
\text { - Lower pH and ammonia nitrogen concentration in the rumen }\end{array}$ & [65] \\
\hline $\begin{array}{l}\text { Piromyces sp. WNG-12, isolated } \\
\text { from wild blue bull }\end{array}$ & $\begin{array}{l}\text { Lactating buffaloes fed wheat } \\
\text { straw and concentrate }(50: 50 \text { on a } \\
\text { DM basis) with additional green } \\
\text { corn }(6 \mathrm{~kg} / \mathrm{d})\end{array}$ & $\begin{array}{l}\text { Fresh fungal culture medium by } \\
\text { oral drenching, daily } \\
\text { administered }\end{array}$ & $\begin{array}{l}\text { - Increased milk yield and milk fat content } \\
\text { - Increased total tract digestibility of DM, organic matter, crude } \\
\text { protein, NDF, and ADF } \\
\text { Higher ruminal concentrations of total SCFA, ammonia nitrogen, } \\
\text { and fungal zoospores } \\
\text { - Higher feed efficiency (milk yield in relation to DM intake) }\end{array}$ & [66] \\
\hline $\begin{array}{l}\text { Orpinomyces sp. C- } 14 \text { isolated } \\
\text { from domesticated cattle }\end{array}$ & $\begin{array}{l}\text { Buffalo calves fed wheat straw, } \\
\text { concentrate and green oats } \\
(45: 45: 10 \text { on a DM basis) }\end{array}$ & $\begin{array}{l}\text { Fresh fungal culture medium by } \\
\text { oral drenching, daily } \\
\text { administered }\end{array}$ & $\begin{array}{l}\text { - Increased total body weight gain and higher feed conversion ratio } \\
\text { Increased total tract digestibility of DM, crude protein, NDF, } \\
\text { and ADF } \\
\text { - Higher ruminal concentrations of total SCFA, ammonia nitrogen, } \\
\text { and fungal zoospores, as well as lower ruminal pH }\end{array}$ & [67] \\
\hline
\end{tabular}


Table 1. Cont.

\begin{tabular}{ll}
\hline AF Strain & Investigated Ruminant Species \\
\hline Piromyces sp. WNG-12, isolated & Buffalo calves fed wheat straw, \\
from wild blue bull & concentrate and green oats \\
& $(45: 45: 10$ on a DM basis $)$
\end{tabular}

Orpinomyces sp. KNGF-2 isolated from Korean native black goat

Orpinomyces sp. KNGF-2 isolated from Korean native black goat

Neocallimastix sp. CF-17 isolated from feces of wild cattle

Neocallimastix sp. CF-17 isolated from feces of wild cattle
Sheep fed orchard grass and concentrate (70:30)
Sheep fed orchard grass and concentrate (70:30) libitum with additional $1 \mathrm{~kg}$ concentrate and $1 \mathrm{~kg}$

green fodder

Buffalo calves fed wheat straw

libitum with additional $1 \mathrm{~kg}$

\section{AF Administration Form}

Fresh fungal culture medium by oral drenching,

daily administered

Fresh fungal culture medium via the rumen cannula before morning feeding, daily administered

Supernatant of fungal culture medium (i.e., fungal enzymes) via the rumen cannula before morning feeding, daily administered

Buffalo calves fed wheat straw ad Encapsulated fungal cells

(rhizomycelia and zoospores) mixed with concentrate, weekly administered

- Increased body weight gain

- Increased total tract digestibility of organic matter and NDF

- Higher ruminal concentrations of total SCFA, carboxymethyl cellulase, and xylanase

- Higher abundance of fungi, as well as total, cellulolytic, and hemicellulolytic bacteria in the rumen

- Increased total tract digestibility of DM and organic matter

Fresh fungal culture medium by oral drenching, weekly administered

\section{Results $^{1}$}

Reference

- Increased total tract digestibility of DM, crude protein, NDF, and ADF

- Higher ruminal concentrations of total SCFA, ammonia nitrogen, and fungal zoospores, as well as lower ruminal $\mathrm{pH}$

Increased ruminal concentration of total SCFA and acetate, as well as lower $\mathrm{pH} 3 \mathrm{~h}$ post-feeding

- Increased ruminal concentration of propionate $9 \mathrm{~h}$ post-feeding

- Higher abundances of fungi and bacteria in the rumen

Increased total tract digestibility of DM, crude protein, NDF, and $\mathrm{ADF}$

- Increased ruminal concentration of butyrate 3 and $6 \mathrm{~h}$ post-feeding

concentrate and $1 \mathrm{~kg}$

green fodder
- Higher ruminal concentrations of total SCFA, carboxymethyl cellulase, and xylanase

- Higher abundance of fungi, as well as total, cellulolytic, and hemicellulolytic bacteria in the rumen
[67] ]

.


Since the development of probiotic AF definitely maintains a long-term challenge, another option for promoting rumen AF by feed additives is implied from yeast-based research data. Indeed, supplementing yeasts to high-grain fed dairy cows alleviated fungal dysbiosis in the rumen as shown by higher AF richness, as well as increased abundances of specific genera, e.g., Neocallimastix [38]. Similarly, Chaucheyras et al. [72] have earlier demonstrated a promoting effect by yeasts on the germination and cellulolytic activity of Neocallimastix frontalis in vitro. Thus, there seems to be chance that no direct AF-based probiotic is needed, but live yeast preparations that are already common feed additives in ruminant nutrition [64] could shape the AF community beneficially. It is therefore conceivable that ameliorations observed in response to yeast supplementation [64] were partly due to changes in the fungal community, which should be further investigated.

Interestingly, yet to be clarified is the impact of feedstuff particle length, which in general is an important aspect of ruminant nutrition research, decisively determining the fermentative processes and health in the rumen and hindgut [13,73]. Recent in vitro data revealed varying fungal fermentation activities in response to different grass leaf lengths as incubation of Neocallimastix frontalis with long particles $(4 \mathrm{~cm})$ resulted in $18.4 \%$ more gas and higher relative acetate formation compared to its incubation with short particles $(0.5 \mathrm{~cm})$ [74]. Although it remains to be solved, whether this in vitro scenario can be transferred to the rumen, it would mean implications on the efficacy of potential AF-based feed additives that could be different with different diet types.

It is worth of notice that AF may not necessarily be applied as direct-fed microbials to be relevant to ruminant nutrition. Apart from their mechanical fiber breakdown, AF exert numerous CAZymes, which can be organized in cellulosomes and that are highly involved in cell wall degradation [5-7]. If isolated appropriately, such fungal enzymes could also be convenient to use as feed additives. So far, the administration of fungal enzymes alone exerts no effect on ruminal fermentation or host performance [68], which is likely ascribed to the rapid degradation of the fungal enzymes in the rumen, thus impeding any potential activity. Provided that the resilience of purified fungal enzymes can be increased, they might become a feed additive in ruminant feeding. Chemical structure modifications, as applied to saponins [75], or a protective agent, analogous to the secretory component of immunoglobulin A that conserves this compound from digestion in the gut [76], may increase the resistance of fungal enzymes in the forestomach and could therefore represent a starting point for further research.

\section{Anaerobic Fungi as Silage Additives}

Ensiling aims to preserve fresh forages via rapid lactic acid fermentation with a maximum recovery of dietary energy and highly digestible nutrients [77]. To achieve this, a variety of microorganisms, their isolated enzymes, or manifold combinations are applied as silage additives [63]. Using AF to affect the ensiling process beneficially, however, has been overlooked until now. Instead, fungi are yet predominantly associated with poor silage quality as the presence of yeasts and molds is linked to aerobic deterioration and mycotoxicoses, respectively, both leading to decreased feed intake, reduced performance, and impaired health of the animal [78,79]. Likewise, investigations on fungal communities in differently produced mixed silages were also related to detrimental fungi only [80].

However, silages may indeed be an application area for AF with great potential as they form numerous CAZymes, which further can be arranged as cellulosomes, as well as physically penetrate fibrous structures during their vegetative stage $[5,6]$. Thus, adding AF at ensiling may lead to an enhanced cleavage of fiber and lignocellulosic biomass, which then would result in an enhanced ruminal fiber degradability. Consequently, plant biomass like straw that is yet widely unexploited in ruminant nutrition could get upvalued and therefore become a more extensively used diet component in ruminant livestock production systems. Such a mode of action was already indicated by two pilot studies investigating the impact of $\mathrm{AF}$ inoculation on quality and ruminal degradation of rice straw or whole crop maize silage [81,82]. The plant materials were ensiled with AF strains isolated from 
herbivore guts, which in both approaches led to an increased ruminal dry matter and fiber degradability during subsequent incubations either in vitro [82] or in situ [81]. Remarkably, compared to the control silages, whole crop maize silages treated with AF also showed an improved silage quality, i.e., higher lactic acid concentrations along with a lower $\mathrm{pH}$ and less acetic acid [82], which was also apparent for $\mathrm{pH}$ in AF-treated rice straw silages [81].

Although these data provide first evidence of the AF potential as silage additives, it has to be noted that the two studies $[81,82]$ on AF-treated silages were conducted at minor labscale. Immense quantities of AF cultures would be necessary to inoculate the large volumes of forage material sufficiently, which are moreover ensiled in very few days on cattle farms. As the production of large amounts of actively growing AF cultures is by now not possible and long-term storage of AF cultures is inevitably associated with substantial viability losses [71], an upscaling to typical silo bunker sizes seems not feasible-particularly when further considering the associated logistical burden for punctually shipping the AF cultures to deployment location without impairments in quality or viability.

Despite this clear limitation in producing AF cultures and in consequence also in using AF as silage inoculants, data of Lee et al. [81] may already implicate a conceivable solution. In fact, fungal populations declined very rapidly after ensiling and the concentrations of thallus-forming units were similar to the control after 60 days [81]. Thus, silages may actually not provide conditions necessary for $\mathrm{AF}$ to survive and proliferate, which in turn also precludes a physical penetration of fiber by fungal rhizoids. However, alterations in fiber fraction concentrations in AF-treated silages were observed and still apparent after 60 days of ensiling, such as a further decrease of the neutral detergent fiber content [81], suggesting that not the AF but their secreted CAZymes and cellulosomes were responsible for the differences in chemical composition and the significantly improved ruminal degradability of silages.

Consequently, it appears that the enzymatic array of AF can be deployed as silage additives. Indeed, AF-derived enzymes possess several advantageous properties, predestinating them for this purpose: fungal CAZymes are widely expressed extracellularly $[24,83]$ and highly effective in degrading cell wall structures over a wide $\mathrm{pH}$ range $(\mathrm{pH} 4-8)$ [82], which is further emphasized by the target affinity of AF CAZymes for recalcitrant fiber components [23], i.e., those that are insufficiently degraded in the forestomach system [84]. The latter AF feature is of particular relevance because less robust fiber structures, such as hemicelluloses, are also degraded by lactic acid-induced acidolysis in the silo [85] or else can later be fermented efficiently by rumen microorganisms [84]. Thus, disassembling also recalcitrant fibrous components would mean a more complete cleavage of plant fiber in the silo than it is likely feasible so far, which may be particularly true for strawy biomass, where enzyme additives are assumed to be more effective [63]. Apart from CAZymes, AF form a variety of cellulosomes that can increase the cellulolytic activity immensely [86] and in contrast to bacteria, fungal cellulosomes are not necessarily attached to the cell wall but largely released into the surrounding $[24,83]$. Regarding the applicability in ruminant nutrition, this would offer the possibility to culture AF and use their spent culture medium (SCM), in which fungal CAZymes and cellulosomes are accumulated [68], as silage additives (Figure 1). 


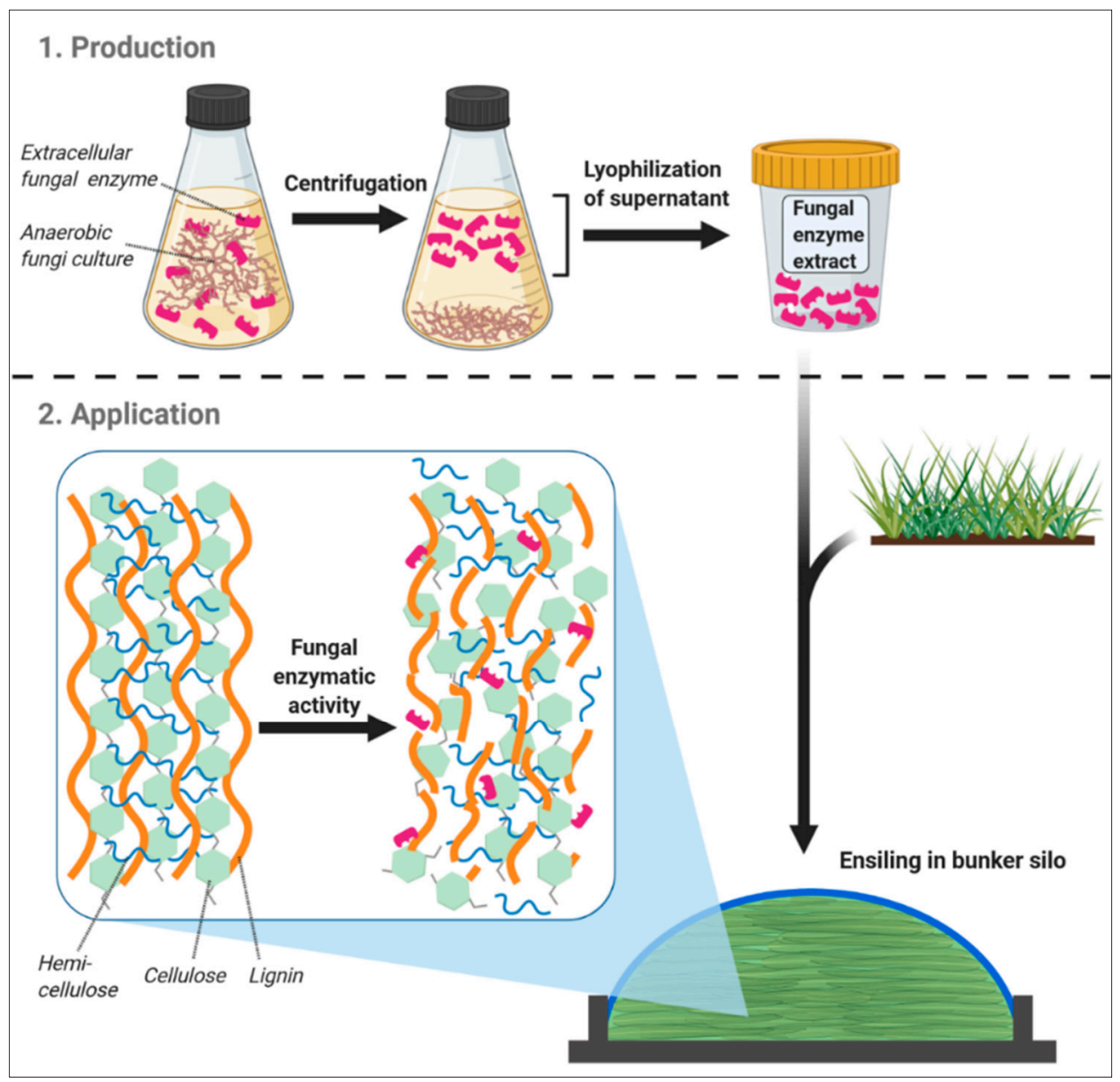

Figure 1. Basic scheme of the production and application of an anaerobic fungi-based silage additive, as well as its potential mode of action during ensiling. Created with BioRender.com.

These fungal cultures may then be cultivated in continuous-flow cultures, where AF showed up to 20 times larger production of cellulolytic enzymes than in batch cultures [20]. A lyophilization step may be included in order to facilitate convenient storage and shipping without significantly impairing fungal enzyme activity [87], and might further be combined with other technologies, such as ultrafiltration, to concentrate AF enzymes [88], and therefore potentate their activity as a silage additive. Although growing of AF cultures on a large scale is yet problematic, such production and processing of fungal SCM could be conducted continuously and therefore better enable an upscaling of fungal enzyme application to silo bunker sizes present in ruminant livestock production.

In fact, using AF-derived CAZymes should allow a much more controlled manipulation of the ensiling process than it would be feasible with inoculating viable AF. First, administering AF enzymes precludes the risk of AF metabolizing easily fermentable carbohydrates in favor of fiber due to catabolite repression, which would otherwise mean an unintentional competition for nutrients between AF and lactic acid bacteria. Instead, further substrate from fungal enzyme-induced lignocellulose solubilization may be available for the lactic acid bacteria, which in parts might explain the improved silage quality observed in AF-inoculated silages [81,82]—or else these released nutrients would subsequently be readily accessible to the rumen microbiota, provided they are not metabolized by yeasts after silo opening, thereby promoting aerobic deterioration of silages. Secondly, literature describes a tannin-degrading activity by several AF strains [89], which may also have implications on the outcome of ensiling. Tannins are frequently applied to preserve true protein in silages [90] and tanninolytic AF could counteract this purpose. Combining 
tannins with AF-derived enzymes, however, would bypass this risk and could yield higher nutritive value of silages, also in terms of protein quality.

\section{Conclusions}

Anaerobic fungi have yet been marginally perceived in ruminant nutrition, particularly when compared to bacteria. However, AF are of outstanding significance for plant cell wall degradation in the rumen-but rather than being relevant for fibrolysis only, AF seem of key importance in other aspects of ruminant nutrition, as well, such as methane formation and nutrient provision to the host. Consequently, it seems prudent and also overdue to consider AF with greater emphasis in prospective ruminant nutrition studies. Indeed, these microorganisms may likely contribute to the clarification of open questions in ruminant feeding that remain unexplained with current knowledge. Regarding the application options in ruminant nutrition, AF may be used as feed additives as well as in silage production. Apart from limitations in the scalability of AF cultivation, advances in AF administration are required to realize higher ruminal fiber degradation as well as improved performance characteristics that have been shown in response to AF treatments of ruminants. Likewise, silage production can become an important application area for AF with their extracellularly produced CAZymes and cellulosomes enabling the successful conservation of forages along with improving their ruminal fiber degradability. Therefore, coming research initiatives should follow up the examination of AF to understand better their role in the gut and how to exploit their application potential optimally, thus shaping tomorrow's ruminant nutrition.

Author Contributions: Writing—original draft preparation, T.H.; writing—review and editing, T.H. and Q.Z.; visualization, T.H.; funding acquisition, T.H. and Q.Z. All authors have read and agreed to the published version of the manuscript.

Funding: Research of T. Hartinger was funded by "Deutsche Forschungsgemeinschaft" (DFG, German Research Foundation), 447776988. Open Access Funding by the University of Veterinary Medicine Vienna.

Institutional Review Board Statement: Not applicable.

Informed Consent Statement: Not applicable.

Data Availability Statement: Data sharing not applicable.

Conflicts of Interest: The authors declare no conflict of interest.

\section{References}

1. Firkins, J.L.; Yu, Z. Ruminant nutrition symposium: How to use data on the rumen microbiome to improve our understanding of ruminant nutrition. J. Anim. Sci. 2015, 93, 1450-1470. [CrossRef] [PubMed]

2. Hartinger, T.; Gresner, N.; Südekum, K.-H. Does intra-ruminal nitrogen recycling waste valuable resources? A review of major players and their manipulation. J. Anim. Sci. Biotechnol. 2018, 9, 33. [CrossRef]

3. Beauchemin, K.A.; Ungerfeld, E.M.; Eckard, R.J.; Wang, M. Review: Fifty years of research on rumen methanogenesis: Lessons learned and future challenges for mitigation. Animal 2020, 14, s2-s16. [CrossRef] [PubMed]

4. Davies, D.R.; Theodorou, M.K.; Lawrence, M.I.; Trinci, A.P. Distribution of anaerobic fungi in the digestive tract of cattle and their survival in faeces. J. Gen. Microbiol. 1993, 139, 1395-1400. [CrossRef]

5. Hess, M.; Paul, S.S.; Puniya, A.K.; van der Giezen, M.; Shaw, C.; Edwards, J.E.; Fliegerová, K. Anaerobic fungi: Past, present, and future. Front. Microbiol. 2020, 11. [CrossRef] [PubMed]

6. Gruninger, R.J.; Puniya, A.K.; Callaghan, T.M.; Edwards, J.E.; Youssef, N.; Dagar, S.S.; Fliegerova, K.; Griffith, G.W.; Forster, R.; Tsang, A.; et al. Anaerobic fungi (phylum Neocallimastigomycota): Advances in understanding their taxonomy, life cycle, ecology, role and biotechnological potential. FEMS Microbiol. Ecol. 2014, 90, 1-17. [CrossRef] [PubMed]

7. Akin, D.E.; Borneman, W.S. Role of rumen fungi in fiber degradation. J. Dairy Sci. 1990, 73, 3023-3032. [CrossRef]

8. Stabel, M.; Hanafy, R.A.; Schweitzer, T.; Greif, M.; Aliyu, H.; Flad, V.; Young, D.; Lebuhn, M.; Elshahed, M.S.; Ochsenreither, K.; et al. Aestipascuomyces dupliciliberans gen. nov, sp. nov., the first cultured representative of the uncultured SK4 clade from Aoudad sheep and alpaca. Microorganisms 2020, 8, 1734. [CrossRef] [PubMed]

9. Vinzelj, J.; Joshi, A.; Insam, H.; Podmirseg, S.M. Employing anaerobic fungi in biogas production: Challenges \& opportunities. Bioresour. Technol. 2020, 300, 122687. [CrossRef] [PubMed] 
10. Rumen Microbiology: From Evolution to Revolution; Puniya, A.K.; Singh, R.; Kamra, D.N. (Eds.) Springer: New Delhi, India, 2015; ISBN 9788132224013.

11. Gressley, T.F.; Hall, M.B.; Armentano, L.E. Ruminant nutrition symposium: Productivity, digestion, and health responses to hindgut acidosis in ruminants. J. Anim. Sci. 2011, 89, 1120-1130. [CrossRef] [PubMed]

12. Henderson, G.; Cox, F.; Ganesh, S.; Jonker, A.; Young, W.; Janssen, P.H. Rumen microbial community composition varies with diet and host, but a core microbiome is found across a wide geographical range. Sci. Rep. 2015, 5, 14567. [CrossRef]

13. Castillo-Lopez, E.; Haselmann, A.; Petri, R.M.; Knaus, W.; Zebeli, Q. Evaluation of fecal fermentation profile and bacterial community in organically fed dairy cows consuming forage-rich diets with different particle sizes. J. Dairy Sci. 2020. [CrossRef] [PubMed]

14. Neubauer, V.; Petri, R.; Humer, E.; Kröger, I.; Mann, E.; Reisinger, N.; Wagner, M.; Zebeli, Q. High-grain diets supplemented with phytogenic compounds or autolyzed yeast modulate ruminal bacterial community and fermentation in dry cows. J. Dairy Sci. 2018, 101, 2335-2349. [CrossRef] [PubMed]

15. Petri, R.M.; Wetzels, S.U.; Qumar, M.; Khiaosa-Ard, R.; Zebeli, Q. Adaptive responses in short-chain fatty acid absorption, gene expression, and bacterial community of the bovine rumen epithelium recovered from a continuous or transient high-grain feeding. J. Dairy Sci. 2019, 102, 5361-5378. [CrossRef]

16. Petri, R.M.; Schwaiger, T.; Penner, G.B.; Beauchemin, K.A.; Forster, R.J.; McKinnon, J.J.; McAllister, T.A. Characterization of the core rumen microbiome in cattle during transition from forage to concentrate as well as during and after an acidotic challenge. PLoS ONE 2013, 8, e83424. [CrossRef] [PubMed]

17. Rezaeian, M.; Beakes, G.W.; Parker, D.S. Distribution and estimation of anaerobic zoosporic fungi along the digestive tracts of sheep. Mycol. Res. 2004, 108, 1227-1233. [CrossRef] [PubMed]

18. Li, S.; Khafipour, E.; Krause, D.O.; Kroeker, A.; Rodriguez-Lecompte, J.C.; Gozho, G.N.; Plaizier, J.C. Effects of subacute ruminal acidosis challenges on fermentation and endotoxins in the rumen and hindgut of dairy cows. J. Dairy Sci. 2012, 95, 294-303. [CrossRef] [PubMed]

19. Czerkawski, J.W.; Breckenridge, G. Design and development of a long-term rumen simulation technique (Rusitec). Br. J. Nutr. 1977, 38, 371-384. [CrossRef]

20. Zhu, W.-Y.; Theodorou, M.K.; Longland, A.C.; Nielsen, B.B.; Dijkstra, J.; Trinci, A.P. Growth and survival of anaerobic fungi in batch and continuous-flow cultures. Anaerobe 1996, 2, 29-37. [CrossRef]

21. Kostyukovsky, V.; Inamoto, T.; Ando, T.; Nakai, Y.; Ogimoto, K. Degradation of hay by rumen fungi in artificial rumen (RUSITEC). J. Gen. Appl. Microbiol. 1995, 41, 83-86. [CrossRef]

22. Khiaosa-Ard, R.; Metzler-Zebeli, B.U.; Ahmed, S.; Muro-Reyes, A.; Deckardt, K.; Chizzola, R.; Böhm, J.; Zebeli, Q. Fortification of dried distillers grains plus solubles with grape seed meal in the diet modulates methane mitigation and rumen microbiota in Rusitec. J. Dairy Sci. 2015, 98, 2611-2626. [CrossRef] [PubMed]

23. Hagen, L.H.; Brooke, C.G.; Shaw, C.A.; Norbeck, A.D.; Piao, H.; Arntzen, M.Ø.; Olson, H.M.; Copeland, A.; Isern, N.; Shukla, A.; et al. Proteome specialization of anaerobic fungi during ruminal degradation of recalcitrant plant fiber. ISME J. 2020. [CrossRef] [PubMed]

24. Haitjema, C.H.; Solomon, K.V.; Henske, J.K.; Theodorou, M.K.; O’Malley, M.A. Anaerobic gut fungi: Advances in isolation, culture, and cellulolytic enzyme discovery for biofuel production. Biotechnol. Bioeng. 2014, 111, 1471-1482. [CrossRef] [PubMed]

25. Lee, S.S.; Ha, J.K.; Cheng, K. Relative contributions of bacteria, protozoa, and fungi to in vitro degradation of orchard grass cell walls and their interactions. Appl. Environ. Microbiol. 2000, 66, 3807-3813. [CrossRef]

26. Ma, Y.; Li, Y.; Li, Y.; Cheng, Y.; Zhu, W. The enrichment of anaerobic fungi and methanogens showed higher lignocellulose degrading and methane producing ability than that of bacteria and methanogens. World J. Microbiol. Biotechnol. 2020, $36,125$. [CrossRef] [PubMed]

27. Hartinger, T.; Edwards, J.E.; Gómez Expósito, R.; Smidt, H.; Ter Braak, C.J.F.; Gresner, N.; Südekum, K.-H. Differently pre-treated alfalfa silages affect the in vitro ruminal microbiota composition. Front. Microbiol. 2019, 10, 2761. [CrossRef] [PubMed]

28. Paul, S.; Kamra, D.; Sastry, V.; Sahu, N.; Agarwal, N. Effect of administration of an anaerobic gut fungus isolated from wild blue bull (Boselaphus tragocamelus) to buffaloes (Bubalus bubalis) on in vivo ruminal fermentation and digestion of nutrients. Anim. Feed Sci. Technol. 2004, 115, 143-157. [CrossRef]

29. Urrutia, N.L.; Harvatine, K.J. Acetate dose-dependently stimulates milk fat synthesis in lactating dairy cows. J. Nutr. 2017, 147, 763-769. [CrossRef] [PubMed]

30. Mobashar, M.; Hummel, J.; Blank, R.; Südekum, K.-H. Contribution of different rumen microbial groups to gas, short-chain fatty acid and ammonium production from different diets-an approach in an in vitro fermentation system. J. Anim. Physiol. Anim. Nutr. 2019, 103, 17-28. [CrossRef]

31. Edwards, J.E.; Forster, R.J.; Callaghan, T.M.; Dollhofer, V.; Dagar, S.S.; Cheng, Y.; Chang, J.; Kittelmann, S.; Fliegerova, K.; Puniya, A.K.; et al. PCR and Omics based techniques to study the diversity, ecology and biology of anaerobic fungi: Insights, challenges and opportunities. Front. Microbiol. 2017, 8, 1657. [CrossRef]

32. Neubauer, V.; Petri, R.M.; Humer, E.; Kröger, I.; Reisinger, N.; Baumgartner, W.; Wagner, M.; Zebeli, Q. Starch-rich diet induced rumen acidosis and hindgut dysbiosis in dairy cows of different lactations. Animals 2020, 10, 1727. [CrossRef] [PubMed]

33. Khafipour, E.; Plaizier, J.C.; Aikman, P.C.; Krause, D.O. Population structure of rumen Escherichia coli associated with subacute ruminal acidosis (SARA) in dairy cattle. J. Dairy Sci. 2011, 94, 351-360. [CrossRef] [PubMed] 
34. Neubauer, V.; Humer, E.; Mann, E.; Kröger, I.; Reisinger, N.; Wagner, M.; Zebeli, Q.; Petri, R.M. Effects of clay mineral supplementation on particle-associated and epimural microbiota, and gene expression in the rumen of cows fed high-concentrate diet. Anaerobe 2019, 59, 38-48. [CrossRef] [PubMed]

35. Belanche, A.; Doreau, M.; Edwards, J.E.; Moorby, J.M.; Pinloche, E.; Newbold, C.J. Shifts in the rumen microbiota due to the type of carbohydrate and level of protein ingested by dairy cattle are associated with changes in rumen fermentation. J. Nutr. 2012, 142, 1684-1692. [CrossRef] [PubMed]

36. Tapio, I.; Fischer, D.; Blasco, L.; Tapio, M.; Wallace, R.J.; Bayat, A.R.; Ventto, L.; Kahala, M.; Negussie, E.; Shingfield, K.J.; et al. Taxon abundance, diversity, co-occurrence and network analysis of the ruminal microbiota in response to dietary changes in dairy cows. PLoS ONE 2017, 12, e0180260. [CrossRef]

37. Plaizier, J.C.; Krause, D.O.; Gozho, G.N.; McBride, B.W. Subacute ruminal acidosis in dairy cows: The physiological causes, incidence and consequences. Vet. J. 2008, 176, 21-31. [CrossRef]

38. Ishaq, S.L.; AlZahal, O.; Walker, N.; McBride, B. An investigation into rumen fungal and protozoal diversity in three rumen fractions, during high-fiber or grain-induced sub-acute ruminal acidosis conditions, with or without active dry yeast supplementation. Front. Microbiol. 2017, 8, 1943. [CrossRef] [PubMed]

39. Kumar, S.; Indugu, N.; Vecchiarelli, B.; Pitta, D.W. Associative patterns among anaerobic fungi, methanogenic archaea, and bacterial communities in response to changes in diet and age in the rumen of dairy cows. Front. Microbiol. 2015, 6, 781. [CrossRef]

40. Han, X.; Li, B.; Wang, X.; Chen, Y.; Yang, Y. Effect of dietary concentrate to forage ratios on ruminal bacterial and anaerobic fungal populations of cashmere goats. Anaerobe 2019, 59, 118-125. [CrossRef]

41. Boots, B.; Lillis, L.; Clipson, N.; Petrie, K.; Kenny, D.A.; Boland, T.M.; Doyle, E. Responses of anaerobic rumen fungal diversity (phylum Neocallimastigomycota) to changes in bovine diet. J. Appl. Microbiol. 2013, 114, 626-635. [CrossRef] [PubMed]

42. Fliegerova, K.O.; Podmirseg, S.M.; Vinzelj, J.; Grilli, D.J.; Kvasnová, S.; Schierová, D.; Sechovcová, H.; Mrázek, J.; Siddi, G.; Arenas, G.N.; et al. The effect of a high-grain diet on the rumen microbiome of goats with a special focus on anaerobic fungi. Microorganisms 2021, 9, 157. [CrossRef] [PubMed]

43. Stauder, A.; Humer, E.; Neubauer, V.; Reisinger, N.; Kaltenegger, A.; Zebeli, Q. Distinct responses in feed sorting, chewing behavior, and ruminal acidosis risk between primiparous and multiparous Simmental cows fed diets differing in forage and starch levels. J. Dairy Sci. 2020. [CrossRef] [PubMed]

44. Hanafy, R.A.; Johnson, B.; Youssef, N.H.; Elshahed, M.S. Assessing anaerobic gut fungal diversity in herbivores using D1/D2 large ribosomal subunit sequencing and multi-year isolation. Environ. Microbiol. 2020, 22, 3883-3908. [CrossRef] [PubMed]

45. Wang, X.; Liu, X.; Groenewald, J.Z. Phylogeny of anaerobic fungi (phylum Neocallimastigomycota), with contributions from yak in China. Antonie Leeuwenhoek 2017, 110, 87-103. [CrossRef] [PubMed]

46. Dijkstra, J.; Bannink, A.; France, J.; Kebreab, E.; van Gastelen, S. Short communication: Antimethanogenic effects of 3nitrooxypropanol depend on supplementation dose, dietary fiber content, and cattle type. J. Dairy Sci. 2018, 101, 9041-9047. [CrossRef] [PubMed]

47. Li, Y.; Meng, Z.; Xu, Y.; Shi, Q.; Ma, Y.; Aung, M.; Cheng, Y.; Zhu, W. Interactions between anaerobic fungi and methanogens in the rumen and their biotechnological potential in biogas production from lignocellulosic materials. Microorganisms 2021, 9, 190. [CrossRef]

48. Yarlett, N.; Orpin, C.G.; Munn, E.A.; Yarlett, N.C.; Greenwood, C.A. Hydrogenosomes in the rumen fungus Neocallimastix patriciarum. Biochem. J. 1986, 236, 729-739. [CrossRef] [PubMed]

49. Bauchop, T.; Mountfort, D.O. Cellulose fermentation by a rumen anaerobic fungus in both the absence and the presence of rumen methanogens. Appl. Environ. Microbiol. 1981, 42, 1103-1110. [CrossRef] [PubMed]

50. Swift, C.L.; Brown, J.L.; Seppälä, S.; O'Malley, M.A. Co-cultivation of the anaerobic fungus Anaeromyces robustus with Methanobacterium bryantii enhances transcription of carbohydrate active enzymes. J. Ind. Microbiol. Biotechnol. 2019, 46, 1427-1433. [CrossRef] [PubMed]

51. Li, Y.; Jin, W.; Mu, C.; Cheng, Y.; Zhu, W. Indigenously associated methanogens intensified the metabolism in hydrogenosomes of anaerobic fungi with xylose as substrate. J. Basic Microbiol. 2017, 57, 933-940. [CrossRef] [PubMed]

52. Wallace, R.; Joblin, K.N. Proteolytic activity of a rumen anaerobic fungus. FEMS Microbiol. Lett. 1985, 29, 19-25. [CrossRef]

53. Sok, M.; Ouellet, D.R.; Firkins, J.L.; Pellerin, D.; Lapierre, H. Amino acid composition of rumen bacteria and protozoa in cattle. J. Dairy Sci. 2017, 100, 5241-5249. [CrossRef] [PubMed]

54. Gresner, N.; Wichern, A.; Lumpp, L.; Hoedemaker, M.; Höltershinken, M. Effects of grass silages with two levels of free amino acids on degradation of amino acids and fixation of nitrogen in bacterial protein in bovine ruminal fluid using the rumen simulation technique (Rusitec). Anim. Feed Sci. Technol. 2015, 202, 1-11. [CrossRef]

55. Gulati, S.K.; Ashes, J.R.; Gordon, G.L.R.; Connell, P.J.; Rogers, P.L. Nutritional availability of amino acids from the rumen anaerobic fungus Neocallimastix sp. LM1 in sheep. J. Agric. Sci. 1989, 113, 383-387. [CrossRef]

56. Kemp, P.; Jordan, D.J.; Orpin, C.G. The free- and protein-amino acids of the rumen phycomycete fungi Neocallimastix frontalis and Piromonas communis. J. Agric. Sci. 1985, 105, 523-526. [CrossRef]

57. Nam, I.S.; Garnsworthy, P.C. Biohydrogenation of linoleic acid by rumen fungi compared with rumen bacteria. J. Appl. Microbiol. 2007, 103, 551-556. [CrossRef] [PubMed]

58. Nam, I.S.; Garnsworthy, P.C. Factors influencing biohydrogenation and conjugated linoleic acid production by mixed rumen fungi. J. Microbiol. 2007, 45, 199-204. [PubMed] 
59. Oliveira, R.C.; Pralle, R.S.; de Resende, L.C.; Nova, C.H.P.C.; Caprarulo, V.; Jendza, J.A.; Troescher, A.; White, H.M. Prepartum supplementation of conjugated linoleic acids (CLA) increased milk energy output and decreased serum fatty acids and $\beta$ hydroxybutyrate in early lactation dairy cows. PLoS ONE 2018, 13, e0197733. [CrossRef] [PubMed]

60. Ávila, G.; Catozzi, C.; Pravettoni, D.; Sala, G.; Martino, P.; Meroni, G.; Lecchi, C.; Ceciliani, F. In vitro effects of conjugated linoleic acid (CLA) on inflammatory functions of bovine monocytes. J. Dairy Sci. 2020, 103, 8554-8563. [CrossRef] [PubMed]

61. McCrorie, T.A.; Keaveney, E.M.; Wallace, J.M.W.; Binns, N.; Livingstone, M.B.E. Human health effects of conjugated linoleic acid from milk and supplements. Nutr. Res. Rev. 2011, 24, 206-227. [CrossRef] [PubMed]

62. Vandamme, E.J. Production of vitamins, coenzymes and related biochemicals by biotechnological processes. J. Chem. Technol. Biotechnol. 1992, 53, 313-327. [CrossRef] [PubMed]

63. Muck, R.E.; Nadeau, E.M.G.; McAllister, T.A.; Contreras-Govea, F.E.; Santos, M.C.; Kung, L. Silage review: Recent advances and future uses of silage additives. J. Dairy Sci. 2018, 101, 3980-4000. [CrossRef] [PubMed]

64. Chaucheyras-Durand, F.; Durand, H. Probiotics in animal nutrition and health. Benef. Microbes 2010, 1, 3-9. [CrossRef] [PubMed]

65. Dey, A.; Sehgal, J.P.; Puniya, A.K.; Singh, K. Influence of an anaerobic fungal culture (Orpinomyces sp.) administration on growth rate, ruminal fermentation and nutrient digestion in calves. Asian Australas. J. Anim. Sci. 2004, 17, 820-824. [CrossRef]

66. Saxena, S.; Sehgal, J.P.; Puniya, A.K.; Singh, K. Effect of administration of rumen fungi on production performance of lactating buffaloes. Benef. Microbes 2010, 1, 183-188. [CrossRef]

67. Tripathi, V.K.; Sehgal, J.P.; Puniya, A.K.; Singh, K. Effect of administration of anaerobic fungi isolated from cattle and wild blue bull (Boselaphus tragocamelus) on growth rate and fibre utilization in buffalo calves. Arch. Anim. Nutr. 2007, 61, 416-423. [CrossRef] [PubMed]

68. Lee, S.; Ha, J.; Cheng, K.-J. Influence of an anaerobic fungal culture administration on in vivo ruminal fermentation and nutrient digestion. Anim. Feed Sci. Technol. 2000, 88, 201-217. [CrossRef]

69. Weimer, P.J. Redundancy, resilience, and host specificity of the ruminal microbiota: Implications for engineering improved ruminal fermentations. Front. Microbiol. 2015, 6, 296. [CrossRef]

70. Paul, S.S.; Deb, S.M.; Punia, B.S.; Das, K.S.; Singh, G.; Ashar, M.N.; Kumar, R. Effect of feeding isolates of anaerobic fungus Neocallimastix sp. CF 17 on growth rate and fibre digestion in buffalo calves. Arch. Anim. Nutr. 2011, 65, 215-228. [CrossRef] [PubMed]

71. Dollhofer, V.; Podmirseg, S.M.; Callaghan, T.M.; Griffith, G.W.; Fliegerová, K. Anaerobic fungi and their potential for biogas production. In Biogas Science and Technology; Gübitz, G.M., Bauer, A., Bochmann, G., Gronauer, A., Weiss, S., Eds.; Springer: Cham, Switzerland, 2015; ISBN 9783319219936.

72. Chaucheyras, F.; Fonty, G.; Bertin, G.; Gouet, P. Effects of live Saccharomyces cerevisiae cells on zoospore germination, growth, and cellulolytic activity of the rumen anaerobic fungus, Neocallimastix frontalis MCH3. Curr. Microbiol. 1995, 31, 201-205. [CrossRef]

73. Zebeli, Q.; Tafaj, M.; Junck, B.; Olschläger, V.; Ametaj, B.N.; Drochner, W. Evaluation of the response of ruminal fermentation and activities of nonstarch polysaccharide-degrading enzymes to particle length of corn silage in dairy cows. J. Dairy Sci. 2008, 91, 2388-2398. [CrossRef] [PubMed]

74. Jimenez, H.R.; Edwards, J.E.; Sanderson, R.; Kingston-Smith, A.H.; McEwan, N.R.; Theodorou, M.K. Cut-lengths of perennial ryegrass leaf-blades influences in vitro fermentation by the anaerobic fungus Neocallimastix frontalis. Microorganisms 2020, 8, 1774. [CrossRef] [PubMed]

75. Ramos-Morales, E.; de la Fuente, G.; Duval, S.; Wehrli, C.; Bouillon, M.; Lahmann, M.; Preskett, D.; Braganca, R.; Newbold, C.J. Antiprotozoal effect of saponins in the rumen can be enhanced by chemical modifications in their structure. Front. Microbiol. 2017, 8, 399. [CrossRef] [PubMed]

76. Lindh, E. Increased resistance of immunoglobulin A dimers to proteolytic degradation after binding of secretory component. J. Immunol. 1975, 114, 284-286. [PubMed]

77. Kung, L.; Shaver, R.D.; Grant, R.J.; Schmidt, R.J. Silage review: Interpretation of chemical, microbial, and organoleptic components of silages. J. Dairy Sci. 2018, 101, 4020-4033. [CrossRef]

78. Fink-Gremmels, J. The role of mycotoxins in the health and performance of dairy cows. Vet. J. 2008, 176, 84-92. [CrossRef] [PubMed]

79. McDonald, P.; Henderson, N.; Heron, S. The Biochemistry of Silage, 2nd ed.; Chalcombe Publications: Marlow, UK, 1991; ISBN 0948617225.

80. Jiang, D.; Zheng, M.L.; Niu, D.Z.; Zuo, S.S.; Tian, P.J.; Li, R.R.; Xu, C.C. Effects of steam explosion pretreatment and Lactobacillus buchneri inoculation on fungal community of unensiled and ensiled total mixed ration containing wheat straw during air exposure. J. Appl. Microbiol. 2019, 128, 675-687. [CrossRef] [PubMed]

81. Lee, S.M.; Guan, L.L.; Eun, J.-S.; Kim, C.-H.; Lee, S.J.; Kim, E.T.; Lee, S.S. The effect of anaerobic fungal inoculation on the fermentation characteristics of rice straw silages. J. Appl. Microbiol. 2015, 118, 565-573. [CrossRef] [PubMed]

82. Wang, D.; Zhao, C.; Liu, S.; Zhang, T.; Yao, J.; Cao, Y. Effects of Piromyces sp. CN6 CGMCC 14449 on fermentation quality, nutrient composition and the in vitro degradation rate of whole crop maize silage. AMB Express 2019, 9, 121. [CrossRef] [PubMed]

83. Haitjema, C.H.; Gilmore, S.P.; Henske, J.K.; Solomon, K.V.; de Groot, R.; Kuo, A.; Mondo, S.J.; Salamov, A.A.; LaButti, K.; Zhao, Z.; et al. A parts list for fungal cellulosomes revealed by comparative genomics. Nat. Microbiol. 2017, 2, 17087. [CrossRef] [PubMed] 
84. Du, S.; Xu, M.; Yao, J. Relationship between fibre degradation kinetics and chemical composition of forages and by-products in ruminants. J. Appl. Anim. Res. 2016, 44, 189-193. [CrossRef]

85. Dewar, W.A.; McDonald, P.; Whittenbury, R. The hydrolysis of grass hemicelluloses during ensilage. J. Sci. Food Agric. 1963, 14, 411-417. [CrossRef]

86. Artzi, L.; Bayer, E.A.; Moraïs, S. Cellulosomes: Bacterial nanomachines for dismantling plant polysaccharides. Nat. Rev. Microbiol. 2017, 15, 83-95. [CrossRef] [PubMed]

87. Sundari, K.S.; Adholeya, A. Retention of enzyme activity following freeze-drying the mycelium of ectomycorrhizal isolates: Part II. Enzymes acting upon carbon compounds. World J. Microbiol. Biotechnol. 2000, 16, 865-868. [CrossRef]

88. Qi, B.; Luo, J.; Chen, G.; Chen, X.; Wan, Y. Application of ultrafiltration and nanofiltration for recycling cellulase and concentrating glucose from enzymatic hydrolyzate of steam exploded wheat straw. Bioresour. Technol. 2012, 104, 466-472. [CrossRef]

89. Paul, S.S.; Kamra, D.N.; Sastry, V.R.B.; Sahu, N.P. Effect of adding an anaerobic fungal culture isolated from a wild blue bull (Boselophus tragocamelus) to rumen fluid from buffaloes on in vitro fibrolytic enzyme activity, fermentation and degradation of tannins and tannin-containing Kachnar tree (Bauhinia variegata) leaves and wheat straw. J. Sci. Food Agric. 2006, 86, 258-270. [CrossRef]

90. Tabacco, E.; Borreani, G.; Crovetto, G.M.; Galassi, G.; Colombo, D.; Cavallarin, L. Effect of chestnut tannin on fermentation quality, proteolysis, and protein rumen degradability of alfalfa silage. J. Dairy Sci. 2006, 89, 4736-4746. [CrossRef] 